\title{
Economic Threshold Level of Chenopodium album L. and Phalaris minor Retz. in Wheat
}

\author{
A. Tanveer', S. Ahmad, R. Ahmad', M. Ayub and A. Ali
}

\author{
Department of Agronomy, University of Agriculture, Faisalabad, Pakistan \\ 'Department of Crop Physiology, University of Agriculture, Faisalabad, Pakistan
}
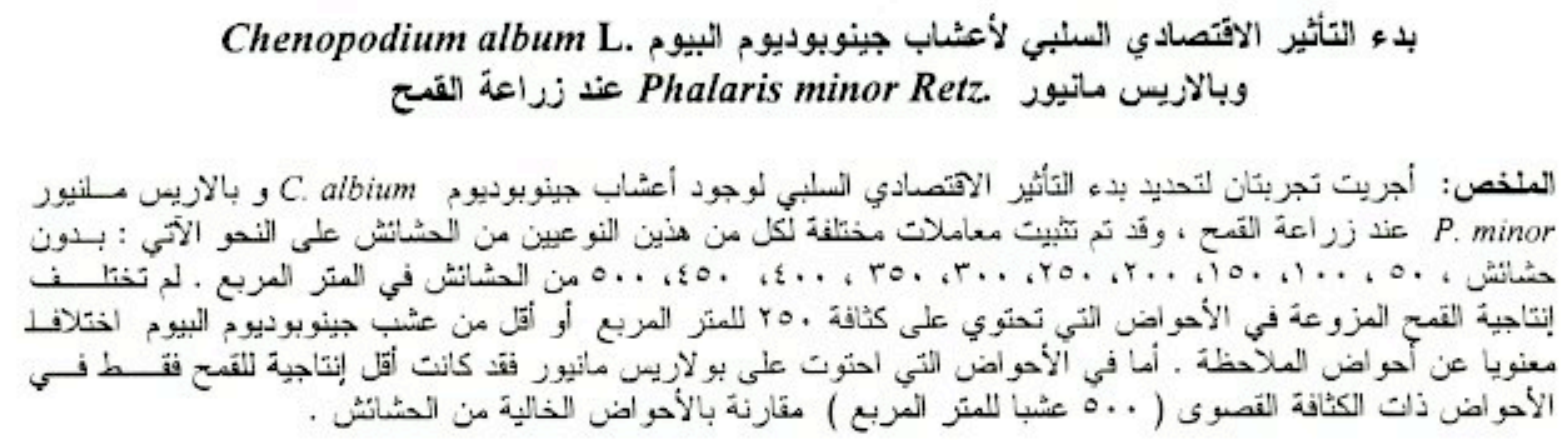

\begin{abstract}
Two field experiments were conducted to determine the economic threshold level of $C$. album and $P$. minor in wheat. Different densities viz., check (weed free), 50,100,150,200, 250,300,350,400, 450 and $500 \mathrm{~m}^{-2}$ of each weed species were maintained separately. Grain yield obtained from plots having $C$. album densities up to $250 \mathrm{~m}^{2}$ was not statistically different from that obtained from weed free plots (check). In $P$. minor, minimum grain yield was obtained at the highest weed density of $500 \mathrm{~m}^{-2}$ as compared with that in the absence of weeds.
\end{abstract}

$\mathrm{W}$ eed infestation in wheat fields is a critical factor limiting wheat yield. Crop plants suffer from stress created by weeds through competition for light, nutrients and moisture. The magnitude of the stress, depends upon the type and density of weed. Since growth and reproductive behaviour of different weeds varies, threshold density levels are also different for each weed species.

Kolar et al. (1977) concluded that Chenopodium album L. infestation, at an average density of 200 mature plants $\mathrm{m}^{-2}$, resulted in $40 \%$ reduction of grain yield mainly due to reduced tillering of wheat. Roder et al. (1986) pointed out that Chenopodium album L. densities ranging from 50-400 plants $\mathrm{m}^{-2}$ resulted in yield losses of 1.6 to $9.2 \%$ in winter cereals. Costa et al. (1978) observed that the Phalaris minor Retz. population of 343 plants $\mathrm{m}^{-2}$ caused a $28 \%$ reduction in yields of winter wheat. Cudney and Hill (1979) observed 60 and $40 \%$ reduction in yield of wheat $\mathrm{cv}$. Yecora Rojo in the presence of 280 and 33 plants $\mathrm{m}^{-2}$ of Phalaris minor Retz., respectively. Godinko and Costa (1980) noted that in the weedy check plots of Phalaris minor Retz., 350 plants $\mathrm{m}^{-2}$ caused $37 \%$ reduction in wheat yield.
Tiwari et al. (1984) found that Phalaris minor Retz. ranging in density from 29 to 926 plants $\mathrm{m}^{-2}$ reduced grain yield by decreasing tillering, grain weight of wheat ear ${ }^{-1}$ and crop biomass. Mehra and Gill (1988) reported that an increase in the population of Phalaris minor Retz. from 50 to 250 seedlings $\mathrm{m}^{-2}$ reduced the grain yield of wheat from 7.6 to $44.2 \%$ in the field. Carlson (1986) reported that as the proportion of Avena fatua $\mathrm{L}$. increased in relative terms, its deleterious effect on wheat declined, apparently due to increased competition with existing Avena fatua L. plants. Wimschneider et al. (1990) found that four Avena fatua L. (wild oat) plants in a pot containing 16 wheat plants reduced yield by $9 \%$ while 8 wild oats reduced yield by $14 \%$. Studies by Cheema and Nazir (1996) revealed that Avena fatua L. growing in association with wheat caused yield reduction of $12.64,17.90,28.98,36.34$ and $45.75 \%$ in grain yield at weed densities of 10,20 , 30,40 and 50 plants $\mathrm{m}^{-2}$, respectively. This study employed a standard wheat crop density of 200 plants $\mathrm{m}^{-2}$. Ibrahim et al. (1994) studied populations of Chenopodium album L., Phalaris minor Retz. and Avena fatua L. at $0,11,19,27$ and $36 \%$ of wheat plants. Weed levels of 0,11 and $19 \%$ did not affect the

*Corresponding Author. 
grain yield which was about $4.63,4.53$ and $4.43 \mathrm{t} \mathrm{ha}^{-1}$. However, yields were significantly lower at $27(3.87 \mathrm{t}$ $\left.\mathrm{ha}^{-1}\right)$ and 36\% (3.50 t ha $\left.{ }^{-1}\right)$ levels. Angonin and Caussanel (1992) reported decreased wheat yield as densities of Poa annua L. and Lolium multiflorum Lam. increased from 0 to 1200 plants $\mathrm{m}^{-2}$. In this study the wheat density was 240 plants $\mathrm{m}^{2}$. Friesen et al. (1992) recorded that Malva pusilla densities of 237 plants $\mathrm{m}^{-2}$ reduced wheat yield by $15 \%$.

Information on the threshold level of different weeds affecting field crops in Pakistan is scanty. This type of material is vital in order to formulate a proper weed control strategy. Thus, the objective of the present work was to determine the maximum population of $C$. album and $P$. minor that can be tolerated in wheat without incurring economic crop loss.

\section{Materials and Methods}

Two experiments were conducted separately for each one of the species. The experiments were laid out in a randomized complete block design in two different fields. Wheat variety Pasban-90 was sown with a single row hand drill in rows lying $25 \mathrm{~cm}$ apart. A typical plot comprises four rows of $2 \mathrm{~m}$ length and occupies $2 \mathrm{~m}^{2}$. To estimate the threshold level of $C$. album L., wheat was sown on 8 th November and 2nd December in 1992/93 and 1993/94, respectively. In the case of $P$. minor Retz., wheat was sown on 8th December and 7th November in 1992/93 and 1993/94, respectively. Chemical and physical analysis of soil is given in Table 1.

Nitrogen and phosporus were applied at the rate of $115 \mathrm{~kg} \mathrm{ha}^{-1}$ each in the form of urea and single super phosphate, respectively. Half of nitrogen and the whole of phosphorus were side dressed by a drill at sowing and the remaining half of nitrogen was broadcasted at the first irrigation 15 days after emergence. Density levels for each weed species were 0 (weed free), 50 , $100,150,200,250,300,350,400,450$ and 500 plants $\mathrm{m}^{2}$. The field history served as a guidance for the availability of naturally occurring weed species. Populations of both species exceeded the maximum required. Weeds in excess of the desired level were removed every four days by hand pulling. Densities were maintained for 60 days following vestigial cropping. The crop was harvested at maturity, tied into bundles and allowed to sundry for 12 days. After manual threshing, grain weight for each plot was recorded. Then grain yield per plot was converted to kilogram per hectare. Data collected were analysed statistically using the Fisher's analysis of variance. Least Significant Difference (LSD) test at the 5\% probability level was applied to examine the significance of treatment means as described by Steel and Torrie (1984).

\section{Results and Discussion}

As shown in Table 2, the experimental setting unveils the effect of $C$. album and $P$. minor on the flag-leaf area during both years. In 1992/93 the flagleaf area of wheat in check (weed free) was not significantly different from that of 50 and 100 plant $\mathrm{m}^{-2}$ of C. album but gave the highest leaf area. C. album at 50,100 and 150 density levels also produced statistically similar flag-leaf areas. The corresponding area at 500 plant $\mathrm{m}^{-2}$ of $C$. album was the lowest. During 1993/94, C. album in check (weed free), 50 and 100 density levels produced higher and statistically similar flag-leaf areas, than the remaining populations. C. album at 100, 150, 200 and 250 density levels resulted in similar flag-leaf areas of wheat. The lowest flag-leaf area was recorded at 500 plants $\mathrm{m}^{-2}$. Statistically, however this was similar to the flag-leaf area at 200, 250, 300, 350, 400 and 450 density levels of $C$. album.

Flag-leaf area of wheat (Table 2) under different $P$. minor densities varied considerably. Maximum flag leaf area was recorded under check and was statistically

TABLE 1

Chemical and physical analysis of soil

\begin{tabular}{|c|c|c|c|c|c|}
\hline \multirow[t]{3}{*}{ Determination } & \multirow[t]{3}{*}{ Unit } & \multicolumn{4}{|c|}{ Value } \\
\hline & & \multicolumn{2}{|c|}{ Wheat - $C$, album } & \multicolumn{2}{|c|}{ Wheat - P. minor } \\
\hline & & $92 / 93$ & $93 / 94$ & $92 / 93$ & $93 / 94$ \\
\hline Total N & $\%$ & 0.045 & 0.038 & 0.058 & 0.049 \\
\hline Available P & $\mathrm{ppm}$ & 6.5 & 40 & 6.5 & 5.5 \\
\hline Exchangeable $\mathrm{K}$ & $\mathrm{ppm}$ & 181 & 149 & 214 & 180 \\
\hline Soil Water pH & & 8.05 & 7.75 & 7.90 & 7.90 \\
\hline $\mathrm{Ec}$ & $\mathrm{dsm}-1$ & 0.33 & 0.41 & 0.24 & 0.25 \\
\hline Organic matter & \% & 0.72 & 0.45 & 0.81 & 0.84 \\
\hline Soil type & & \multicolumn{2}{|c|}{ Sandy loam } & \multicolumn{2}{|c|}{ Sandy clay loam } \\
\hline
\end{tabular}




\section{ECONOMIC THRESHOLD LEVEL OF CHENOPODIUM ALBUM L. AND PHALARIS MINOR RETZ. IN WHEAT}

TABLE 2

Effect of different densities of C. album and $P$. minor on flag leaf area $\left(\mathrm{cm}^{2}\right)$ plant ${ }^{I}$ of wheat

\begin{tabular}{|c|c|c|c|c|}
\hline \multirow{3}{*}{ Weed density $\left(\mathrm{m}^{-2}\right)$} & \multicolumn{4}{|c|}{ Flag leaf area } \\
\hline & \multicolumn{2}{|c|}{ C. album } & \multicolumn{2}{|c|}{ P. minor } \\
\hline & $92 / 93$ & $93 / 94$ & $92 / 93$ & $93 / 94$ \\
\hline Check (weed free) & $18.56^{\circ}$ & $19.08^{*}$ & $18.43^{*}$ & $19.88^{\circ}$ \\
\hline 50 & $18.47^{a t}$ & $18.56^{4}$ & $18.16^{\circ n}$ & $18.22^{\mathrm{ks}}$ \\
\hline 100 & $17.15^{\text {sc }}$ & $17.61^{\mathrm{ph}}$ & $18.94^{x}$ & $18.04^{\text {tad }}$ \\
\hline 150 & $17.07^{\mathrm{*}}$ & $16.74^{k e}$ & $18.19^{\mathrm{hb}}$ & $18.38^{2 \mathrm{~h}}$ \\
\hline 200 & $16.36^{c}$ & $16.48^{\text {tad }}$ & $16.55^{\mathrm{t}}$ & $17.74^{\text {tade }}$ \\
\hline 250 & $16.90^{\mathrm{C}}$ & $16.27^{\text {tee }}$ & $16.70^{\kappa c}$ & $17.24^{\text {rodat }}$ \\
\hline 300 & $16.52^{c}$ & $15.87^{\circ 4}$ & $16.87^{\mathrm{s}}$ & $16.40^{\text {tf }}$ \\
\hline 350 & $16.49^{c}$ & $15.52^{\mathrm{d}}$ & $16.33^{c}$ & $16.63^{\text {et }}$ \\
\hline 400 & $16.43^{\mathrm{c}}$ & $15.45^{\circ 4}$ & $16.54^{\mathrm{E}}$ & $16.68^{\text {eet }}$ \\
\hline 450 & $16.55^{\circ}$ & $15.34^{.4}$ & $16.53^{\mathrm{c}}$ & $16.72^{\text {teder }}$ \\
\hline 500 & $14.63^{\circ}$ & $15.13^{4}$ & $16.68^{\mathrm{ks}}$ & $15.81^{t}$ \\
\hline SR & 0.49 & 0.52 & 0.53 & 0.52 \\
\hline LSD $5 \%$ & 1.43 & 1.50 & 1.54 & 1.51 \\
\hline Significance & * & $* *$ & * & * \\
\hline
\end{tabular}

Means sharing the same letter do not differ significantly at $\mathrm{P}<0.05$.

similar to that recorded at $P$. minor densities of 50,100 and 150 during 1992/93. The remaining density levels produced relatively lower flag-leaf area and were at par with one another. During 1993/94 check, producing the maximum flag-leaf area, remained at par with the 150 density level of $P$. minor which in turn was comparable with weed density levels of 50,100, 200 and 250 . Wheat attained the lowest flag-leaf area at the density level of 500. Increasing weed density in both species produced a linear decline in the flag-leaf area of wheat.

It is evident from Table 2 that serious reduction in flag-leaf area of wheat occurred beyond the 150 density level. Increasing flag-leaf area up to the 150 density level was probably due to a symbiotic existence between weeds and wheat which in the presence of adequate environmental resources favoured the latter. Competition between weeds and wheat due to increasing weed densities beyond 150 resulted in small flag-leaf areas of wheat. These results are in line with the findings of Akhtar (1991). He recorded the highest leaf area in weed-free check and at low weed density $\left(50 \mathrm{~m}^{-2}\right), 150$ days after emergence. The lowest leaf area of wheat was recorded at weed density of $200 \mathrm{~m}^{-2}$.

The densities of $C$. album did not influence significantly the plant height during 1992/93 and
1993/94 (Table 3). Plant height was in the range of 82.65 to $86.90 \mathrm{~cm}$ and 77.80 to $83.80 \mathrm{~cm}$ during $1992 / 93$ and 1993/94, respectively. Plant height of wheat decreased linearly with the increase in density of $P$. minor during both years. In 1992/93, check, 50, 100 and $150 \mathrm{P}$. minor densities produced relatively tall plants and were at par among themselves. A similar trend was observed for the 1993/94 cultivation.

Decreased plant height of wheat as a result of competition with $P$. minor was probably due to the similar root system of both. At low densities, competition was less thus allowing growth of plants with maximum height. Majid and Sandhu (1984) also reported decreased plant height of wheat due to Fumaria parviflora $\mathrm{L}$. infestation at 50 and $100 \%$ weed densities.

The density levels of $C$. album and $P$. minor significantly affected the grain yield during both years (Tables 4 and 5). In both cases, C. album densities up to $250 \mathrm{~m}^{-2}$ (Table 4) did not reduce grain yields significantly which were comparable to those of the check. Then there was a considerable decrease in grain yield with increasing density of $C$. album. It varied from 20 to $42 \%$ in $1992 / 93$ and 26 to $41 \%$ in $1993 / 94$ at the densities of 300 and 500 plants $\mathrm{m}^{-2}$ respectively. Density level of 500 produced the minimum yield but was statistically at par with those of 450,400 and 350 C. album.

TABLE 3

Effect of different densities of C. album and P. minor on plant height $(\mathrm{cm})$ of wheat

\begin{tabular}{|c|c|c|c|c|}
\hline \multirow{3}{*}{ Weed density $\left(\mathrm{m}^{-2}\right)$} & \multicolumn{4}{|c|}{ Plant height } \\
\hline & \multicolumn{2}{|c|}{ C. album } & \multicolumn{2}{|c|}{ P. minor } \\
\hline & $92 / 93$ & $93 / 94$ & $92 / 93$ & $93 / 94$ \\
\hline Check (weed free) & 86.15 & 83.22 & $94.70^{\circ}$ & $96.20^{\circ}$ \\
\hline 50 & 86.70 & 83.80 & $92.90^{\circ \prime}$ & $93.10^{\circ}$ \\
\hline 100 & 86.40 & $83 .(x)$ & $91.00^{\mathrm{zh}}$ & $92.25^{\text {"h }}$ \\
\hline 150 & 86.90 & $\times 2.45$ & $91.25^{\text {she }}$ & $91.95^{b}$ \\
\hline 200 & 85.60 & 82.30 & $89.95^{\text {ind }}$ & $90.57^{\mathrm{bc}}$ \\
\hline 250 & 85.40 & 82.00 & $89.20^{\text {sad }}$ & $89.95^{\mathrm{b} d \mathrm{~d}}$ \\
\hline 300 & 85.25 & 81.00 & $88.57^{\text {cd }}$ & $86.80^{\text {cde }}$ \\
\hline 350 & 83.05 & 80.88 & $88.88^{\text {od }}$ & $86.15^{\text {te }}$ \\
\hline 400 & 83.97 & 80.78 & $87.85^{\text {a }}$ & $84.90^{\circ}$ \\
\hline 450 & 83.10 & 80.85 & $87.65^{\text {cd }}$ & $83.25^{\text {ef }}$ \\
\hline 500 & 82.65 & 77.80 & $86.57^{4}$ & $80.32^{r}$ \\
\hline$S \times$ & 2.30 & 1.60 & 1.29 & 1.40 \\
\hline LSD $5 \%$ & 6.65 & 4.62 & 3.73 & 4.04 \\
\hline Significance & NS & NS & $*$ & $* *$ \\
\hline
\end{tabular}

Means sharing the same letter do not differ significantly at $\mathrm{P}<0.05$ 
TABLE 4

Effect of different densities of C. album on grain yield $\left(\mathrm{kg} \bullet \mathrm{ha} \mathrm{a}^{-I}\right)$ of wheat

\begin{tabular}{ccccc}
\hline & \multicolumn{4}{c}{ Grain yield } \\
\cline { 2 - 5 } $\begin{array}{c}\text { Weed density } \\
\left(\mathrm{m}^{-2}\right)\end{array}$ & $92 / 93$ & $\begin{array}{c}\text { Decrease } \\
\text { in yield \% }\end{array}$ & $93 / 94$ & $\begin{array}{c}\text { Decrease } \\
\text { in yield \% }\end{array}$ \\
\hline $\begin{array}{c}\text { Check } \\
\text { (weed free) }\end{array}$ & $6150^{\circ}$ & - & $6125^{\circ}$ & - \\
50 & $6150^{\circ}$ & 0.00 & $6100^{\circ}$ & 0.40 \\
100 & $6125^{\circ}$ & 0.40 & $6025^{\circ}$ & 1.63 \\
150 & $6125^{\circ}$ & 0.40 & $5950^{\circ}$ & 2.85 \\
200 & $6025^{\circ}$ & 2.03 & $5925^{\circ}$ & 3.26 \\
250 & $5825^{\circ}$ & 5.28 & $5900^{\circ}$ & 3.67 \\
300 & $4900^{\circ}$ & 20.32 & $4525^{\circ}$ & 26.12 \\
350 & $4050^{\circ}$ & 34.14 & $4050^{\circ}$ & 33.87 \\
400 & $4000^{\circ}$ & 34.95 & $4050^{\circ}$ & 33.87 \\
450 & $3925^{\circ}$ & 36.17 & $4025^{\circ}$ & 34.28 \\
500 & $3575^{\circ}$ & 41.86 & $3575^{\circ}$ & 41.63 \\
\hline
\end{tabular}

Means sharing the same letter do not differ significantly at $\mathrm{P}<0.05$.

As regards $P$. minor during $1992 / 93$, check and the density level of 50 produced the maximum grain yield (Table 5) and did not differ significantly from each other. Density levels of 100, 150, 200 and 250 did not differ significantly from one another either. The density level of 500 produced the minimum yield which was statistically similar to those given by 450,400 , and 350 densities. During 1993/94, check resulted in the highest grain yield and was followed by the $P$. minor density level of 50. P. minor at the density level of 100 produced statistically a similar yield to the 150 density which in turn, was at par with the 200 and 250 density levels. Further, the lowest grain yield was produced by the density level of 500. The trend of grain yield in $P$. minor densities was the same as in $C$. album. Decrease in grain yield was in the range of 4.31 to $40.94 \%$ in $1992 / 93$ and 6.57 to $42.10 \%$ in $1993 / 94$.

Data in Tables 4 and 5 indicate that there was a significant decrease in grain yield with increasing density levels of $C$. album beyond 250 plants $\mathrm{m}^{-2}$ and $P$. minor beyond 50 plants $\mathrm{m}^{-2}$ during both years. The decrease in grain yield with increasing weed density could be related to weed crop competition which resulted in decreased availability of water, nutrients, light, air and space to crop plants. It is also evident from data that the decrease in grain yield started at lower density levels in the case of $P$. minor than $C$. album. This may be due to the competitive ability of $P$ minor for growth factors. Hence, $P$. minor could have enjoyed favourable environmental conditions which allowed it to compete well with wheat and reduce the crop yield at a low experimental presence.
TABLE 5

Effect of various density levels of $P$. minor on grain yield $\left(\mathrm{kg} \cdot \mathrm{ha} \mathrm{a}^{-1}\right)$ of wheat

\begin{tabular}{|c|c|c|c|c|}
\hline \multirow[b]{2}{*}{$\begin{array}{l}\text { Weed density } \\
\qquad\left(\mathrm{m}^{-2}\right)\end{array}$} & \multicolumn{4}{|c|}{ Grain yield } \\
\hline & $92 / 93$ & $\begin{array}{l}\text { Decrease } \\
\text { in yield } \%\end{array}$ & $93 / 94$ & $\begin{array}{l}\text { Decrease } \\
\text { in yield } \%\end{array}$ \\
\hline $\begin{array}{c}\text { Check } \\
\text { (weed free) }\end{array}$ & $58000^{\circ}$ & . & $5700^{\circ}$ & - \\
\hline 50 & $5550^{\prime \prime}$ & 4.31 & $5325^{h}$ & 6.57 \\
\hline 100 & $4525^{\circ}$ & 21.98 & $4375^{\circ}$ & 23.24 \\
\hline 150 & $4475^{\prime}$ & 22.84 & $4150^{\circ}$ & 27.19 \\
\hline $2(x)$ & $42000^{k=}$ & 27.58 & $40500^{\mathrm{k}=}$ & 28.94 \\
\hline 250 & $4175^{\text {te }}$ & 28.01 & $3950^{\mathrm{et}}$ & 30.70 \\
\hline 300 & $400 x 0^{2 x}$ & 31.03 & $23825^{\mathrm{efk}}$ & 32.79 \\
\hline 350 & $3775^{\circ}$ & 34.91 & $3775^{4}$ & 33.77 \\
\hline 400 & $370 x y^{2 x}$ & 36.201 & $3675^{\circ}$ & 35.52 \\
\hline 450 & $34.75^{\circ}$ & 40.08 & $3600 \%$ & 36.84 \\
\hline 500 & $34.25^{\circ}$ & 40.94 & $3300^{\prime \prime}$ & 42.10 \\
\hline
\end{tabular}

Means sharing the same letter do not differ significantly at $\mathrm{P}<0.05$.

Kolar et al. (1977), Roder et al. (1986) and Ibrahim et al. (1994) have also observed a decrease in grain yield caused by deteriorating growth components at densities of Chenopodium album L. up to $400 \mathrm{~m}^{-2}$. According to the findings of Costa et al. (1978), Cudney and Hill (1979), Godinko and Costa (1980), Tiwari et al. (1984) and Mehra and Gill (1988), use of Phalaris minor Retz. densities between 29 and $926 \mathrm{~m}^{-2}$ resulted in a reduction in grain yield from 28 to $60 \%$.

The relatively smaller decrease in grain yield which was observed when the density level was raised beyond $350 \mathrm{~m}^{-2}$ should be the result of increasing competition among weeds. Ultimately, infighting reduced their competitiveness against wheat. These results are in line with work by Carlson (1986), who reported decreased competitiveness of $A$. fatua $\mathrm{L}$. against wheat with increasing densities level of the weed.

In conclusion, results indicate that weed density of $C$. album up to 250 plants $\mathrm{m}^{-2}$ had no adverse effect on grain yield, whereas weed density of $P$. minor beyond 50 plants $\mathrm{m}^{-2}$ was critical and resulted in considerable reduction in grain yield.

\section{References}

Akhtar, M. 1991. Studies on Phalaris minor Retz. interference in wheat at different durations of infestation and nutritional regimes. Ph.D. Thesis, Department of Agronomy, University of Agriculture, Faisalabad, Pakistan.

Angonin, C. and J.P. Caussanel. 1992. Effect of the density of two weed species (Poa annua L. and Lolium multiflorum Lam) on the yield of spring wheat. Ixe Colleue International sur la Biologie des Mauvaises Herbes, 16-18: 315-325. [Weed Abst. 


\section{ECONOMIC THRESHOLD LEVEL OF CHENOPODIUM ALBUM L. AND PHALARIS MINOR RETZ. IN WHEAT}

42(3): 930; 1993.]

Carlson, H.L. 1986. Wild oats (Avena fatua L.) competition with spring wheat (Triticum aestivum L.). Dissertation Absts. International (Scis. and Engineering) 46(7): 2177. [Weed Absts. 37(2): 636; 1988.]

Cheema, M.S. and M.S. Nazir. 1996. Evaluation of economic threshold level of wild oat (Avena fatua L.) for herbicidal use in wheat. Absts. 5th Pakistan Weed Sci. Conf.: 2-3.

Costa, J.C., I. Godinho, L. Trinidade and M. Bica. 1978. Winter wheat yields and competition from Phalaris minor Retz. Agricultura: 164-165. [Weed Absts. 30(1): 15; 1981].

Cudney, D.W.and J.E. Hill. 1979. The response of wheat grown with three population levels of canary grass to various herbicide treatments. Proc. Western Soc. Weed Sci. 32: 5566. Dept. Bot. and Plant Sci., Univ. California, USA. [Weed Absts. 29(7): 1895; 1980].

Friesen, L.F., K.P. Nickel and I.N. Morrison. 1992. Round leaved mallow (Malva pusilla) growth and interference in spring wheat and flax. Weed Sci. 40(3): 448-554. [Weed Absts. 42(3): 935; 1993].

Godinko, I. and J.C.A. Costa. 1980. Competition of Phalaris minor Retz. in wheat. Sinosio Nacional de Herbologia. 3: 227-243. [Weed Absts. 31(8): 2528; 1982].

Ibrahim, M., A. Khan, M.I. Khan and N. Ahmad. 1994. Wheat yield decrease due to various weeds infestation densities. 4 th Pakistan Weed Sci. Conf. Univ. of Agric. Faisalabad: 9.

Kolar, J.S., D.S. Bains and G.S. Gill. 1977. Competition between wheat and Chenopodium album L. The effect of weed removal at different stages of crop growth. Indian J. Ecology 4(1): 66-70. [Weed Absts. 29(7): 2117; 1980].

Majid, A. and G.R. Sandhu. 1984. Effects of Fumaria parviflora L. on yield and yield components of wheat. Pakistan J. Agric. Res. 5(3): 141-143.

Mehra, S.P. and H.S. Gill. 1988. Effect of temperature on germination of Phalaris minor Retz. and its competition in wheat. Indian J. Res. 25(4): 529-533. [Weed Absts. 38(7): 2075; 1989].

Roder, W., G. Feyerabend, H. Eggert, A. Kalmus and H. Lattke. 1986. On the assessment of the interaction damage relationship in winter cereal stands. Nachrickten blatt fur den Pflangensehutz in der DDR. 40 (10): 200-203. [Weed Absts. 36(3): 737; 1987].

Steel, R.G.D. and J.H. Torrie. 1984. Principles and Procedures of Statistics. 2nd Ed. McGraw Hill Book Company, Singapure: $172-177$.

Tiwari, J.P., C.R. Bisen and K.M. Gangrade. 1984. Correlation of weed parameters with growth and yield of wheat. Indian J. Weed Sci. 16(4): 276-280. [Weed Absts. 35(10): 3592; 1986].

Wimschneider, W., G. Bachthaler and G. Fischbeck. 1990. Competitive effect of Avena fatua L. (wild oats) on wheat (Triticum aestivum L.) as a basis for effective weed control. Weed Res. 30(1): 43-52. [Weed Absts. 39(3): 795; 1990]. 